University of Nebraska - Lincoln

DigitalCommons@University of Nebraska - Lincoln

6-1985

Reticulotaenia n. gen. for Lateriporus australis Jones and

Williams, 1967, and Lateriporus mawsoni Prudhoe, 1969

(Cestoda: Dilepididae), from Sheathbills, Chionis spp., in Antarctica, with a Consideration of Infraspecific Variation and

Speciation

Eric P. Hoberg

United States Department of Agriculture, eric.hoberg@ars.usda.gov

Follow this and additional works at: https://digitalcommons.unl.edu/parasitologyfacpubs

Part of the Parasitology Commons

Hoberg, Eric P., "Reticulotaenia n. gen. for Lateriporus australis Jones and Williams, 1967, and Lateriporus mawsoni Prudhoe, 1969 (Cestoda: Dilepididae), from Sheathbills, Chionis spp., in Antarctica, with a Consideration of Infraspecific Variation and Speciation" (1985). Faculty Publications from the Harold W. Manter Laboratory of Parasitology. 314.

https://digitalcommons.unl.edu/parasitologyfacpubs/314

This Article is brought to you for free and open access by the Parasitology, Harold W. Manter Laboratory of at DigitalCommons@University of Nebraska - Lincoln. It has been accepted for inclusion in Faculty Publications from the Harold W. Manter Laboratory of Parasitology by an authorized administrator of DigitalCommons@University of Nebraska - Lincoln. 


\title{
RETICULOTAENIA N. GEN. FOR LATERIPORUS AUSTRALIS JONES AND WILLIAMS, 1967, AND LATERIPORUS MAWSONI PRUDHOE, 1969 (CESTODA: DILEPIDIDAE), FROM SHEATHBILLS, CHIONIS SPP., IN ANTARCTICA, WITH A CONSIDERATION OF INFRASPECIFIC VARIATION AND SPECIATION
}

\author{
Eric P. Hoberg \\ Department of Pathobiology SC-38, University of Washington, Seattle, Washington 98195
}

\begin{abstract}
Reticulotaenia n. gen. was established in the family Dilepididae for 2 species of cestodes, formerly referred to Lateriporus Fuhrmann, 1907, that are characteristic helminths in sheathbills, Chionis spp., in Antarctica. The new genus was most similar to Lateriporus and Dilepis Weinland, 1858, but was easily distinguished from these and other genera of Dilepidinae having a unilateral genital pore. The salient features of Reticulotaenia were a rostellum armed with a single row of 10 hooks, a vaginal sphincter, and a reticulate ovary and uterus. Reticulotaenia australis (Jones and Williams, 1967) n. comb. was redescribed on the basis of specimens from Chionis alba (Gmelin) collected near Palmer Station, Antarctica. Morphological variation in this species of cestode was evaluated in specimens from the South Orkney Islands (type locality) and South Georgia. In addition, R. mawsoni (Prudhoe, 1969) n. comb. from Chionis minor Hartlaub was distinguished from its congener. The present host and geographic distribution of $R$. australis and $R$. mawsoni appeared to represent a result of hostparasite cospeciation.
\end{abstract}

During a study of helminths of seabirds at Palmer Station, Antarctica, numerous cestodes were found in 4 of 5 American sheathbills, Chionis alba (Gmelin), in December 1981 and January 1982 (Hoberg, 1983). Some of these cestodes represented a previously unrecognized genus of Dilepidinae which is characterized in the present paper.

In Antarctica 4 species (in 3 genera) of Dilepidinae have been reported from sheathbills, $C$. alba and C. minor Hartlaub (Fuhrmann, 1921; Jones and Williams, 1967; Prudhoe, 1969; Williams et al., 1974; Szelenbaum-Cielecka and Zdzitowiecki, 1979). Two of these species were originally described in the genus Lateriporus Furhmann, 1907. L. australis Jones and Williams, 1967 , is a characteristic parasite of C. alba and has been collected at Signy Island, South Orkney Islands (type locality) and at Bird Island, South Georgia (Jones and Williams, 1967; Williams et al., 1974). Specimens representing $L$. mawsoni Prudhoe, 1969, were originally collected from C. minor on the Kerguelen Islands and Crozets Islands by $\mathrm{T}$. $\mathrm{H}$. Johnston during the BANZ Antarctic Expedition of 1929-1931 (Prudhoe, 1969). According to their original descriptions, the type specimens of both species were generally in poor condition, being highly

Received 27 July 1984; revised 30 November 1984; accepted 3 December 1984. contracted or fragmented. Specimens of $L$. australis later reported by Williams et al. (1974) were not examined in detail following collection.

Some of these specimens of $L$. australis and $L$. mawsoni were reexamined during the present study. The conspecific identity of cestodes from Palmer and $L$. australis from other localities was confirmed by a comparison with known specimens. Additionally, it was found that both species had been mistakenly assigned to Lateriporus in their original descriptions. These species are here referred to Reticulotaenia $\mathbf{n}$. gen. and $R$. australis is redescribed based on specimens from Palmer, Antarctica. The degree of infraspecific variation in some morphological characters in isolated populations of $R$. australis from Palmer (Antarctic Peninsula), South Georgia and the South Orkney Islands is evaluated.

\section{MATERIALS AND METHODS}

Sheathbills were collected on Cormorant Island, adjacent to Palmer Station, and necropsied immediately. Living cestodes were allowed to relax in saline prior to fixation in boiling $10 \%$ formalin. Helminths were stained in Semichon's acetic carmine and prepared as whole mounts. In some cases rostellar hooks were mounted separately to ensure accurate determination of their size and form. Eggs and oncospheres were examined from both formalin-fixed and mounted specimens. The following redescription is based on $30 \mathrm{spec}-$ imens mounted entire. In the redescription, all measurements are expressed as length vs. width in micrometers unless stated otherwise; ranges of measurements are followed by mean values in parentheses and 

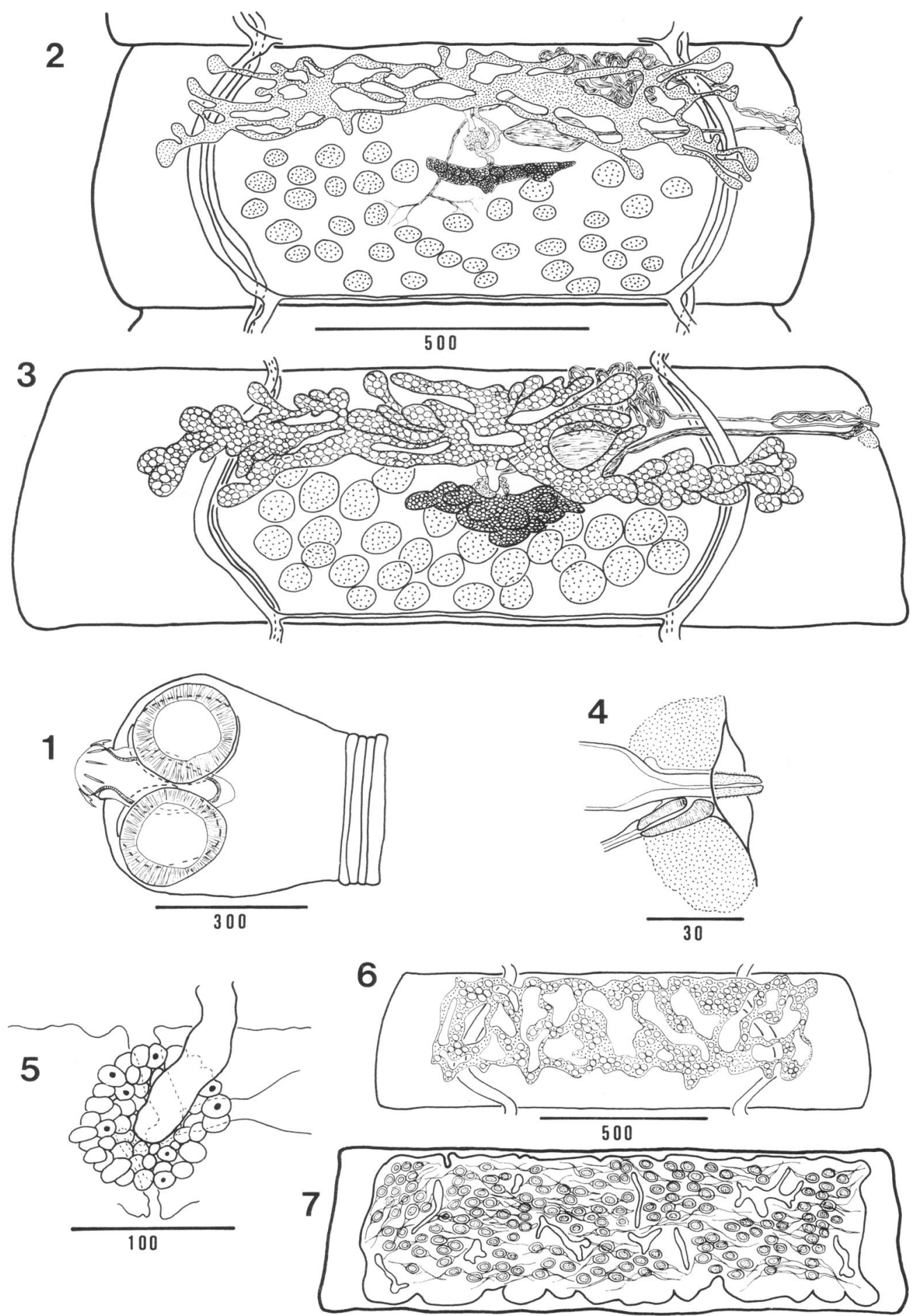

FIGURES 1-7. Reticulotaenia australis n. comb. (Jones and Williams, 1967). 1. Scolex. 2. Early mature proglottid, ventral view. 3. Mature proglottid, ventral view (same scale as Fig. 2). 4. Detail of genital atrium, ventral view, showing vaginal sphincter and spinous cirrus. 5. Detail of female duct system, dorsal view, showing oviduct, vitelline duct, seminal duct, Mehlis gland and ascending uterus. 6. Pregravid proglottid, ventral view, showing reticulate structure of uterus. 7. Gravid proglottid, ventral view, showing sacculate structure of uterus and eggs with polar filaments (same scale as Fig. 6). All scale lines are in micrometers. 
sample sizes for some measurements are given as $(\mathrm{n}=)$.

Other specimens examined: Lateriporus australis Jones and Williams, 1967: 1) sectioned material and a single scolex from the type host, C. alba, and locality, Signy Island, South Orkney Islands, from the collection of I. C. Williams; 2) a single unmounted specimen submitted with the type series (British Museum of Natural History No. 1968.2.21.2-5); 3) 6 whole mounted specimens from C. alba at Bird Island, South Georgia, from the collections of I. C. Williams; 4) Lateriporus mawsoni Prudhoe, 1969: a single slide with 3 complete specimens from the type host, $C$. minor minor, and locality, Kerguelen Islands, and a single unmounted specimen from $C$. m. crozettensis from Possession Island, Crozets Islands (British Museum of Natural History Nos. 1975.1.16.29-36 and 1975.1.16.13-28, respectively). The cestodes received in preservative were stained and mounted according to the above methods. Holotypes of $R$. australis and $R$. mawsoni were not examined.

\section{DIAGNOSIS AND REDESCRIPTION Reticulotaenia n. gen.}

Diagnosis: Dilepidinae. Cestodes of small to medium dimensions. Scolex armed with 10 hooks distributed in a single row. Proglottids craspedote; wider than long. Genital pore unilateral, marginal. Genital ducts passing between poral osmoregulatory canals. Cirrus pouch cylindrical, reaching, or just crossing poral osmoregulatory canals. Cirrus armed. Testes numerous, primarily posterior but may overlap female organs in antiporal half of proglottid. Ovary reticulate, later developing transversely elongate lobes extending beyond osmoregulatory canals. Vitelline gland postovarian. Vagina posterior, ventral to cirrus sac; distally with well developed muscular sphincter. Seminal receptacle pyriform, median. Uterus ventral, initially a flat reticulum of coarse tubules and membranous trabeculae; thin-walled, sacculate, filling entire proglottid beyond excretory canals when gravid. Eggs with bi-polar filaments. Parasites of sheathbills (Charadriiformes: Chionididae).

Type species: Reticulotaenia australis (Jones and Williams, 1967) n. comb.

Other species: Reticulotaenia mawsoni (Prudhoe, 1969) n. comb.

Hosts: Chionis alba (Gmelin) and C. minor Hartlaub, respectively.

Etymology: The name Reticulotaenia refers to the reticulate structure of the ovary and uterus.

\section{Reticulotaenia australis (Jones and Williams, 1969)}

(Figs. 1-8)

General redescription: Maximum length of strobila 39-60 mm with 196-220 proglottids when gravid. Proglottids wider than long; $290-410$ by $1,406-1,743$ in mature; $381-586$ by $1,817-2,520$ in gravid proglottids. Length : width ratio of mature segments $1: 3.5-5.4$; gravid segments 1:4.1-5.2. Neck short; 260-372 wide. Scolex 345-425 wide. Suckers well developed, 148186 in greater diameter. Rostellum $232-290$ by $87-$ 113 at apex; armed with single row of 10 hooks (in one 11); hooks $(n=107$ from 16 scolices) $38-55$ (49) long; handle generally longer than blade, blade : handle ratio 1:0.89-1.38. Rostellar sac $203-305$ by $110-154$, extending posteriad between suckers. Ventral longitudinal excretory canals $20-32$ in diameter; ventral transverse duct 9-12; dorsal canals 6-20. Genital pores unilateral, not prominent, located marginally in anterior third of segment; genital ducts passing between osmoregulatory canals.

Male genitalia: Genital Anlagen visible in 25th-30th segment; testes in 50th-90th; fully mature by 140th160 th proglottid. Cirrus sac cylindrical, short, may attain or just cross poral osmoregulatory canals; $(n=$ 125) 87-174 (128) by 17-32 (22). Cirrus short, cylindrical $(n=30), 4-10(8)$ in diameter when evaginated; armed with minute spines. Vas deferens prominent, convoluted, situated in anterior in poral half of proglottid. Testes ( $n=140$ in 20 strobila) 22-50 (37) in number, located primarily posterior to female organs but may substantially overlap in antiporal half of segment; distributed in 2-3 layers; $(n=200) 35-107(56)$ in diameter.

Female genitalia: Vagina 260-578 long, entering genital atrium ventral and slightly posterior to cirrus sac; extending mediad and expanding to form large, pyriform seminal receptacle $(n=123)$ 151-261 (198) by 61-142 (87), situated near center of segment dorsal to ovary. Vagina and seminal receptacle thin-walled; distal portion of vagina at genital atrium with powerfully developed muscular sphincter. Ovary ventral, reticulate, initially visible in 120 th-130th segment as a network of granular cytoplasmic cords and trabeculae in anterior half of segment. Later development by elongation of transverse lobes extending beyond osmoregulatory canals. Ovary generally with 2 wings when fully developed; overall $648-1,416$ by $94-248$. Vitelline gland lobate, transversely elongate, postovarian, ventral to seminal receptacle; $(n=123)$ 177-378 $(258)$ by $35-96$ (63). Mehlis gland dorsal to vitelline gland and seminal receptacle, $(\mathrm{n}=78)$ 58-102 (70) in diameter. Uterus arises from dorsal surface of Mehlis; develops ventrally, initially visible in 145 th-180th segment as a flat reticulum composed of thin-walled tubules and trabeculae; later assuming a sacculate-lobate structure and extending well beyond the excretory canals when gravid. Lobes of uterus also extend ventrad and dorsad through cortex to level just below tegument. Outer egg envelope with long polar filaments; overall length up to 790 . Ovoid embryophore $(n=60) 29-44$ (36) by 23-29 (25). Oncosphere $(n=60)$ 19-32 (26) by 15-23 (18). Embryonic hooks $(n=53) 9-12$ (10) long.

Host: Chionis alba (Gmelin).

Locality: Cormorant Island, Arthur Harbor, Anvers Island, Antarctica (ca. lat. $64^{\circ} 46^{\prime} \mathrm{S}$; long. $64^{\circ} 05^{\prime} \mathrm{W}$ ).

Habitat: Anterior quarter of small intestine.

Specimens: USNM Helm. Coll. Nos. 78249 and 78250, from Chionis alba at Palmer Station, 28-XII1982 and 1-I-1983, collected by A. F. Betzel and E. P. Hoberg.

Remarks: A second species, Lateriporus mawsoni Prudhoe, 1969, is also transferred to Reticulotaenia. Specimens of $R$. mawsoni n. comb. reexamined during this study, although collected from the type locality in the Kerguelen Islands, were not apparently included in the type series. Prudhoe (1969) listed Chionis minor minor (from several localities among the Kerguelen Islands) and $C$. $m$. crozettensis (Possession Island, Crozets Islands) as hosts for this cestode. However, he did not indicate whether a specific group of specimens 
TABLE I. A morphological comparison of Reticulotaenia spp. from Chionis alba and Chionis minor.

\begin{tabular}{|c|c|c|c|c|c|}
\hline & \multicolumn{3}{|c|}{ Reticulotaenia australis } & \multicolumn{2}{|c|}{ Reticulotaenia mawsoni } \\
\hline & Palmer Station* & Signy Island $\dagger$ & South Georgia $\ddagger$ & $\begin{array}{c}\text { Kerguelen } \\
\text { Island } \$\end{array}$ & $\begin{array}{c}\text { Kerguelen } \\
\text { Island\| }\end{array}$ \\
\hline $\begin{array}{l}\text { Strobila }(L \times W) \\
\text { Segments }(\#)\end{array}$ & $\begin{array}{l}\text { Up to } 60 \mathrm{~mm} \times 2.5 \\
196-222 \text { (gravid) }\end{array}$ & $\begin{array}{l}15-20 \mathrm{~mm} \times 0.8-1.7 \\
160-250\end{array}$ & $\begin{array}{l}-1.6 \mathrm{~mm} \\
\text { Fragmented }\end{array}$ & $\begin{array}{l}40 \mathrm{~mm} \times 3.0 \\
190-250 \text { (gravid) }\end{array}$ & $\begin{array}{l}16-25 \mathrm{~mm} \times 0.8-1.0 \\
113-157 \text { (gravid) }\end{array}$ \\
\hline Hooks (\#) & 10 & 10 & 10 & 10 & 10 \\
\hline Hooks (L) & $38-55(49)$ & $50 \pi$ & $53-64(60)(n=16)$ & $47-50$ & $46-49$ \\
\hline Scolex (W) & $342-425$ & $430-460$ & $387-413$ & $370-420$ & $366-413$ \\
\hline Suckers (W) & $148-180$ & - & $145-174$ & $150-200$ & $139-188$ \\
\hline Testes (\#) & $22-50(37)$ & $35-45$ & $36-54(42)(n=30)$ & $23-30$ & $20-28(24)(n=20)$ \\
\hline Testes (W) & $35-107(56)$ & - & $29-46(36)(n=35)$ & 50 & $20-44(34)(n=45)$ \\
\hline Cirrus sac (L) & $87-174(128)$ & $100-140$ & $96-136(110)$ & 125 & $78-189(121)$ \\
\hline$(W)$ & $17-32(22)$ & $30-40$ & $23-29(25)(n=32)$ & 30 & $29-35(30)(n=30)$ \\
\hline Cirrus & Armed & Unarmed & - & Unarmed & - \\
\hline Seminal re- (L) & $151-261(198)$ & $200-230$ & $131-212(168)$ & 87 & $58-102(85)$ \\
\hline ceptacle (W) & $61-142(87)$ & $62-100$ & $46-73(59)(n=38)$ & 50 & $49-81(61)(n=18)$ \\
\hline Vitelline (L) & $177-378(258)$ & - & $136-197(159)$ & $50-110$ & $55-87(68)$ \\
\hline gland $(W)$ & $35-96(63)$ & - & $39-49(37)(n=20)$ & $20-50$ & $29-46(36)(n=18)$ \\
\hline Ovary $(L \times W)$ & $684-1,416 \times 94-248$ & - & $684-1,003 \times 71-142$ & $650 \times 370$ & $189-531 \times 58-87$ \\
\hline Ovary (Form) & Reticulate & Bilobed & Reticulate & Lobed & Reticulate \\
\hline Uterus (Form) & Reticulate & Sacculate & Reticulate & Sacculate & Reticulate \\
\hline Embryophore (L) & $29-44(36)$ & Not observed & $29-43(33)$ & $25-37$ & $35-44(39)$ \\
\hline$(\mathrm{W})$ & $23-29(25)$ & & $17-26(23)(n=25)$ & & $23-30(28)(n=25)$ \\
\hline Oncosphere (L) & $19-32(26)$ & Not observed & $22-31(25)$ & - & $23-31(28)$ \\
\hline$(\mathrm{W})$ & $15-23(18)$ & & $14-20(17)(n=25)$ & & $16-23(20)(n=25)$ \\
\hline
\end{tabular}

* Specimens from Chionis alba, represented in the redescription.

$\dagger$ From the original description based on specimens from C. alba by Jones and Williams (1967).

¥ Specimens from Chionis alba reported by Williams et al. (1974) but not previously redescribed.

§ From the original description based on specimens from Chionis minor by Prudhoe (1969).

$\|$ Specimens from C. minor collected by T. H. Johnston but not included in the type series.

I Rostellar hooks were found to be $44-52 \mu \mathrm{m}(49)(\mathrm{n}=10)$ in a reexamination of some specimens of $R$. australis from Signy Island.

() Denotes mean values for some measurements.

$(\mathrm{n}=)$ Denotes the sample sizes for some measurements.

was used in preparing the description. Among the material examined for this study, the reticulate structure of the ovary and uterus was evident, thus establishing the congeneric status with $R$. australis. Although similar to those described by Prudhoe (1969), these specimens differed in several characters (Table I). These cestodes were notably smaller and possessed fewer proglottids when gravid than those included in the type series. The ovary was also considerably smaller, but this could be an allometric relationship. There was little variation in such diagnostic characters as the size of rostellar hooks, cirrus sac and number of testes.

The 2 nominal taxa are morphologically very similar (Table I), but can be distinguished by several characters. The rostellar hooks of $R$. mawsoni are indistinguishable from those of $R$. australis (Table I; Fig. 11). Prudhoe (1969) differentiated these 2 species by the number and distribution of testes. The latter character is apparently of no importance. The range in numbers of testes completely overlaps between the 2 species (particularly when $R$. australis from Palmer is compared with $R$. mawsoni), but the mean number is considerably different; $\bar{x}=37$ at Palmer, $\bar{x}=42$ at South Georgia, and $\bar{x}=24$ for $R$. mawsoni. The vitelline gland, seminal receptacle, and ovary are notably smaller in specimens of $R$. mawsoni. In addition the vitelline gland is compact in specimens referred to $R$. mawsoni while it is transversely elongate in $R$. australis.

\section{DISCUSSION}

\section{Systematics}

Reticulotaenia $\mathrm{n}$. gen. is distinguished from all known genera of Dilepidinae possessing unilateral genital pores by a small number of rostellar hooks distributed in a single row, a vagina that distally has a prominent muscular sphincter, a reticulate and transversely lobate ovary, a reticulate uterus, and eggs with polar filaments. It appears to be most similar to Dilepis Weinland, 1858 , and Lateriporus Fuhrmann, 1907. In contrast to Reticulotaenia, Dilepis is characterized by 2 rows of rostellar hooks, genital ducts dorsal to the osmoregulatory canals, an ovary that is highly lobate and never reticulate, a vagina without muscular modification, and a reticulate uterus (according to Spasskaia and Spasskii [1971, 1977]; and evident in specimens of $D$. undula [Schrank, 1788] examined during this study). The uterus is apparently reticulate rather than being sacculate as indicated by Fuhrmann (1932), Wardle and McLeod (1952) and others. Reticulo- 
taenia is readily distinguished from Lateriporus, which possesses a prominent papilla-like genital pore, a lobate ovary, a vagina without muscular modification, and a sacculate uterus. The latter organ develops initially as a narrow, ventral, arcuate tube that later expands and becomes a highly lobate sac. The uterus is thin-walled in Reticulotaenia as opposed to the thick-walled organ in Lateriporus. Two other genera, Anomolepis Spasskaia, Iurpalova, and Korniushin, 1968, and Malika Woodland, 1929, are also characterized by a unilateral genital pore but differ from $R e$ ticulotaenia in having 2 rows of rostellar hooks and a lobed ovary (Spasskaia and Spasskii, 1978). The reticulate and later sacculate uterus of $R e$ ticulotaenia differs from that in Malika, which is initially reticulate but eventually has eggs contained in uterine tubules (Spasskaia and Spasskii, 1978) or in capsules (Schmidt, 1970).

\section{Infraspecific variation}

Cestodes representing populations of $R$. australis from the 3 localities are compared in Table I. Specimens from both Palmer and South Georgia differed in some morphological details from cestodes collected at the type locality. This suggests some degree of geographic variation exists, possibly indicative that endemic populations of $R$. australis might be restricted to specific geographic regions. Substantial variation was noted in the length and form of the rostellar hooks, numbers of testes, and dimensions of the cirrus sac, vitelline gland and seminal receptacle.

Rostellar hooks: The length of the rostellar hooks was highly variable. Hooks from specimens at Palmer and Signy Island exhibited a similar range in size and form (Table I; Figs. 8, 9). Specimens with either small or large hooks were represented at both localities. The former cestodes appeared to be distinct from the more typical, large-hooked forms. However, this difference was not correlated with any other morphological characters having diagnostic value. It is probable that the range in size and form of hooks observed in material from Palmer and Signy represents nonsignificant morphological variation. The largest rostellar hooks were seen in specimens from South Georgia (Table I; Fig. 10). Although the range in length of hooks overlaps when specimens from Palmer and South Georgia are compared, the mean length was substantially greater in the latter locality. This difference could be an indication of some degree of isolation be- tween populations of $R$. australis from South Georgia and those on islands adjacent to the Antarctic Peninsula.

Testes: The range in number of testes in specimens from Palmer was greater than formerly recognized for $R$. australis (Table $\mathrm{I}$ ). This broad range is recognized as variation, as the number of testes per proglottid in a specific strobila was highly variable. Specimens with the greatest number of testes were found at South Georgia.

Other organs: The dimensions of the cirrus sac, vitelline gland, and seminal receptacle were substantially greater in specimens from Palmer as compared with those from either Signy or South Georgia. However, there was considerable overlap in the values for these measurements (Table I). Although numerical values for length of rostellar hooks, number of testes, and dimensions of some organs in some situations, represent statistically discrete ranges associated with specimens from a particular geographic locality, absolute differences could not be defined. Additional material will be required to evaluate fully any possible relationships.

\section{Host ecology}

The potential for endemism among populations of $R$. australis and $R$. mawsoni might be a consequence of host-behavior, particularly nestsite tenacity. The respective hosts $C$. alba and $C$. minor are allopatric with the latter maintaining highly isolated and nonmigratory breeding populations represented by 4 subspecies restricted to the Kerguelen Islands ( $C$. minor minor), Heard Island (C. m. nasicornis), Prince Edward and Marion Islands (C. m. marionensis), and the Crozet Islands (C. m. crozettensis) in the Indian Ocean sector of the Subantarctic (Watson et al., 1971; Watson, 1975). The great distances separating these localities, from $800 \mathrm{~km}$ to $3,500 \mathrm{~km}$, greatly diminishes the chances for successful dispersal by lesser sheathbills. Populations of $C$. alba appear to be resident (and probably philopatric) at some localities throughout the year in the region of the Antarctic Peninsula and adjacent islands, in the South Orkneys and at South Georgia (Jones, 1963; Parmelee et al., 1977). Seasonal movements have been observed from the South Orkneys and South Georgia toward the Falkland Islands and South America but these are typically sporadic and probably do not involve a high proportion of the breeding population (Murphy, 1936; Jones, 1963). As a con- 


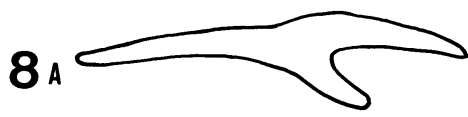

9 A
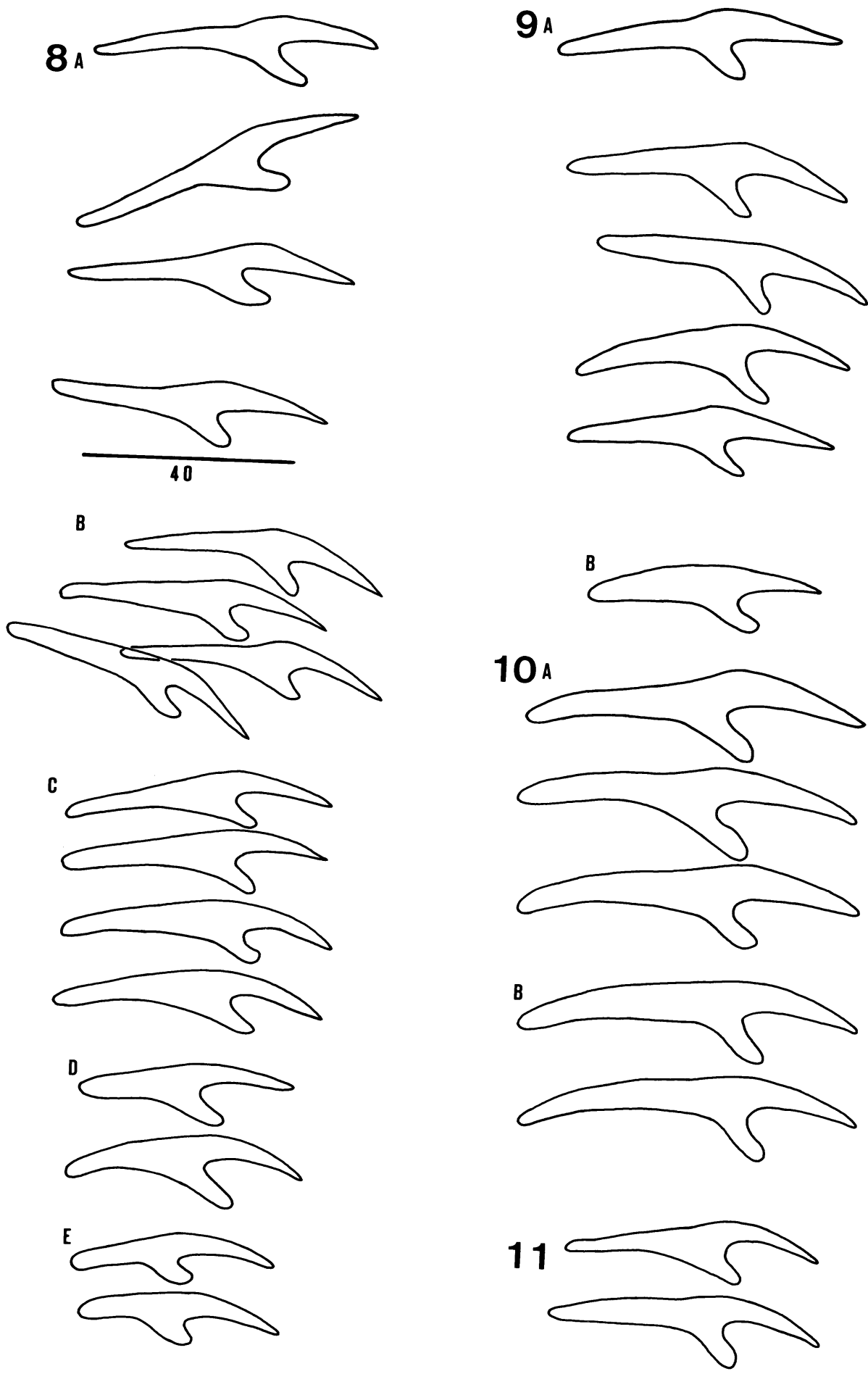

Figures 8-11. Rostellar hooks of Reticulotaenia australis: 8A-E. From 5 specimens at Palmer Station. 9A, B. From 2 specimens, type locality, Signy Island. 10A, B. From 2 specimens at South Georgia. 11. Rostellar hooks from Reticulotaenia mawsoni collected on the Kerguelen Islands. All hooks are shown in the same scale in micrometers. 
sequence there would be minimal interchange among populations of American sheathbills from South Georgia, the South Orkney Islands, and the Antarctic Peninsula. Habitat suitable for nesting is isolated and the distance between any of these latter localities ranges from $950 \mathrm{~km}$ to $2,000 \mathrm{~km}$.

Outside of the breeding season, exchange of helminths among resident populations of sheathbills is unlikely. The sedentary and philopatric behavior of American and lesser sheathbills would tend to enhance the potential for endemism of their typical helminth faunas. With respect to acquisition of prey, both species have broad food-habits. During the breeding season they are typically scavengers in colonies of penguins and shags. Foraging also occurs in intertidal areas where molluscs, particularly the limpet Patinigera polaris (Hombron and Jacquinot, 1841), and crustacea, including amphipods, are the principal prey (Murphy, 1936; Jones, 1963; Jones and Williams, 1969). However, due to icescouring in shallow, inshore habitats and other harsh conditions, the array of potential intermediate hosts is limited at most localities (Jones and Williams, 1969; Hoberg, unpubl. data).

Although the life cycles of both species of $R e$ ticulotaenia are unknown, it is most likely that transmission of these cestodes occurs predominantly in areas where sheathbills breed. Jones and Williams (1969) and Williams et al. (1974) found juvenile sheathbills infected with $R$. australis at Signy Island and Bird Island, respectively. Immature specimens of $R$. australis were found in several adult birds collected at Palmer during this study. Thus, it appears that the cycle is also being completed in that area of the Antarctic Peninsula in addition to localities farther to the north. Assuming there is no substantial interchange of helminths among $C$. alba on the wintering grounds, then philopatry may enhance the isolation of particular populations of $R$. australis.

Speciation: The 2 species of Reticulotaenia apparently represent host-specific parasites of Chionis spp., with $R$. australis being found in $C$. alba and $R$. mawsoni only in $C$. minor. These cestodes are poorly differentiated morphologically but along with their hosts are highly allopatric. It is probable that Reticulotaenia sp. was a parasite of Chionis sp. prior to the isolation and subsequent divergence of $C$. alba and $C$. minor. The present host and geographic distri- bution of $R$. australis and $R$. mawsoni appear to have been a result of host-parasite cospeciation.

The development of geographic isolates of $R$. australis among populations of American sheathbills in the South Orkney Islands, at South Georgia and the Antarctic Peninsula appear to have occurred following the separation of C.alba and $C$. minor. It is probable that subspecific phylogenesis of $C$. minor, which obtained under greater geographic isolation than that currently influencing populations of $C$. alba, was accompanied by some degree of divergence among allopatric populations of $R$. mawsoni. Adequate samples are not yet available to evaluate this hypothesis. Due to the degree of geographic isolation and morphological differences in specimens representing populations of $R$. australis and $R$. mawsoni it appears justifiable to recognize both species as valid pending examination of additional specimens of the latter.

\section{ACKNOWLEDGMENTS}

This research was conducted at Palmer Station, Antarctica during the austral summer of 1982-1983 and supported by a National Science Foundation Grant, DPP-8115975, to Dr. R. L. Rausch and the author. Field studies were completed with the assistance of Dr. G. Shinn. Some birds were collected by Mr. Albert F. Betzel of the Division of Polar Programs. I am indebted to Capt. Pieter J. Lenie and the crew of the R/V Hero for logistical support during our work in Antarctica. Additional assistance was provided by station personnel at Palmer. This study would not have been possible without comparative specimens of $R$. australis kindly provided by Dr. I. C. Williams and Dr. N. V. Jones of the University of Hull, and specimens of $R$. mawsoni loaned by the British Museum of Natural History. I should also like to thank Dr. R. L. Rausch for reviewing earlier versions of this manuscript.

\section{LITERATURE CITED}

FunrmanN, O. 1921. Die Cestoden der Deutschen Südpolar Expedition 1901-1903. 16. Zoologie 8: 461-524.

. 1932. Les Ténias des Oiseaux. Mem. Univ. Neuchâtel 8: 381 p.

HoberG, E. P. 1983. Preliminary comments on parasitological collections from seabirds at Palmer Station, Antarctica. Antarctic Journal of the United States 18: 206-208.

Jones, N. V. 1963. The sheathbill, Chionis alba (Gmelin), at Signy Island, South Orkney Islands. British Antarctic Survey Bulletin 2: 53-71. 
AND I. C. Williams. 1967. The cestode parasites of the sheathbill, Chionis alba (Gmelin), from Signy Island, South Orkney Islands. Journal of Helminthology 41: 151-160.

$\longrightarrow$, AND —. 1969. The nematode and acanthocephalan parasites of the sheathbill, Chionis alba (Gmelin) at Signy Island, South Orkney Islands and a summary of host parasite relationships in the sheathbill. Journal of Helminthology 43: 59-67.

MurPhy, R. C. 1936. Oceanic birds of South America. American Museum of Natural History, New York, 1,245 p.

Parmelee, D. F., W. R. Fraser, and D. R. Nelson. 1977. Birds of the Palmer Station area. Antarctic Journal of the United States 12: 14-21.

Prudhoe, S. 1969 . Cestodes from birds, fishes, and whales. B.A.N.Z. Antarctic Research Expedition 1929-1931. Series B, Zoology, Vol. 8, Pt. 9, pp. 171-193.

SCHMIDT, G. D. 1970. How to know the tapeworms. W. C. Brown Publishers, Dubuque, Iowa, 266 p.

SpassKaia, L. P., AND A. A. SpasskiI. 1971. Tsestody Ptits Tuvy. Akademiia Nauk Moldavskoi SSSR, Shtiinsta, Kishinev. , AND - 1977. Tsestody Ptits SSSR. Dilepididy Sukhoputnikh Ptits. Akademiia Nauk SSSR Shtiinsta, Kishinev Izdatel'stvo Nauka Moskva, 300 p.

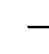
. 1978. Tsestody Ptits SSSR. Dilepididy Limnofil'nikh Ptits. Akademiia Nauk SSSR. Shtiinsta, Kishinev Izdatel'stvo Nauka, Mosvka, 314 p.

Szelenbaum-Cielecka, D., ANd K. Zdzitowiecki. 1979. The tape-worm Nototaenia fileri Jones and Williams, 1967 from the sheathbill (Chionis alba) on King George Island (South Shetlands, Antarctic). Bulletin de l'Academie Polonaise des Sciences. Serie Sciences Biologiques 27: 281-284.

Wardle, R. A., AND J. A. MCLeOd. 1952. The zoology of tapeworms. University Minnesota Press, Minneapolis, Minnesota, 780 p.

WAtson, G. E. 1975. Birds of the Antarctic and Subantarctic. American Geophysical Union, Washington, D.C., 350 p.

, J. P. Angle, P. C. Harper, M. A. Bridge, R. P. Schlatter, W. L. N. Tickell, J. C. Boyd, AND M. M. Boyd. 1971. Birds of the Antarctic and Subantarctic. Antarctic Map Folio Series No. 14. American Geographical Society, pp. 1-18 and Folio.

Williams, I. C., N. V. Jones, M. J. Payne, and C. ELLIS. 1974. The helminth parasites of the sheathbill, Chionis alba (Gmelin), and the diving petrels, Pelecanoides georgicus (Murphy and Harper) and $P$. urinatrix (Gmelin), at Bird Island, South Georgia. Journal of Helminthology 48: 195-197. 